\title{
₹USGS
}

science for a changing world

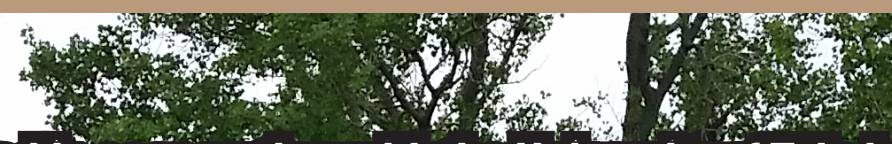

Prepared in cooperation with the University of Toledo

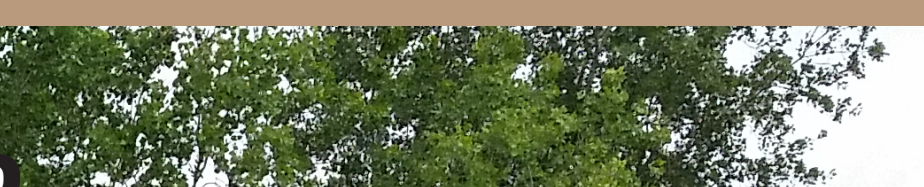

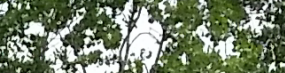
Escherichta coll and Mitcrobial Source Iracking Marker * Concentrations in and Near a Constructed Wetland in (7.) Thamee Bay State Park, Oregon, Ohio, 2015-16
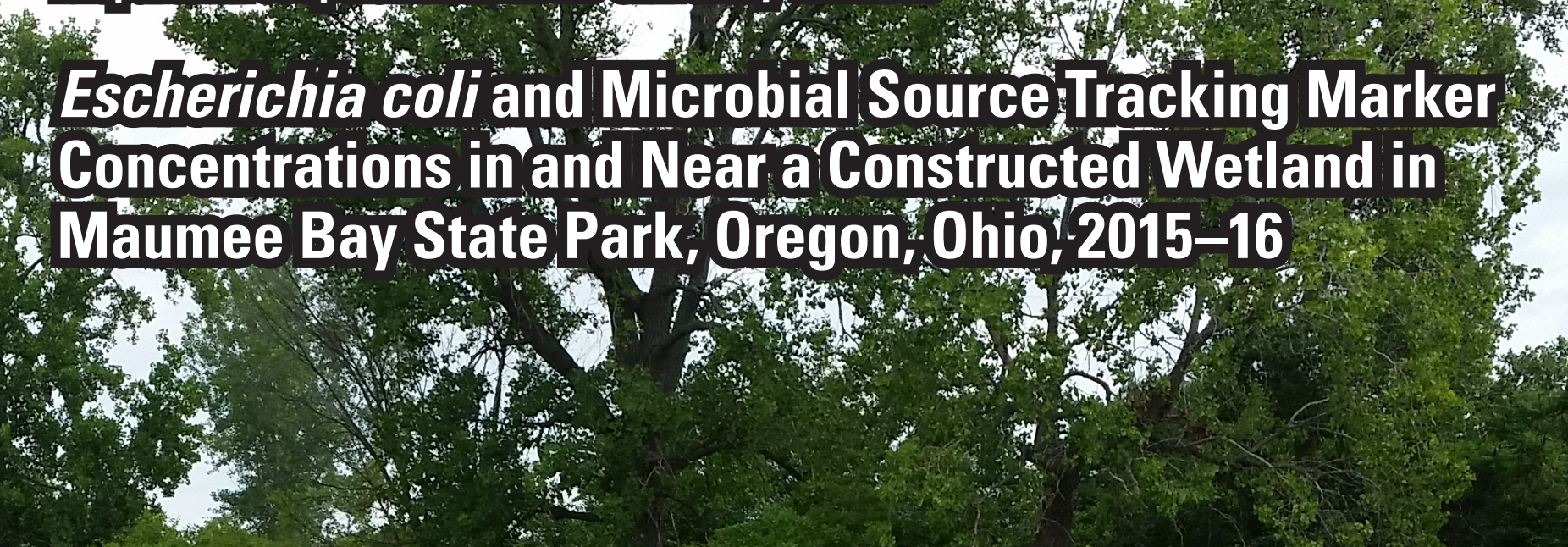

Th:

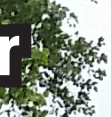

X.
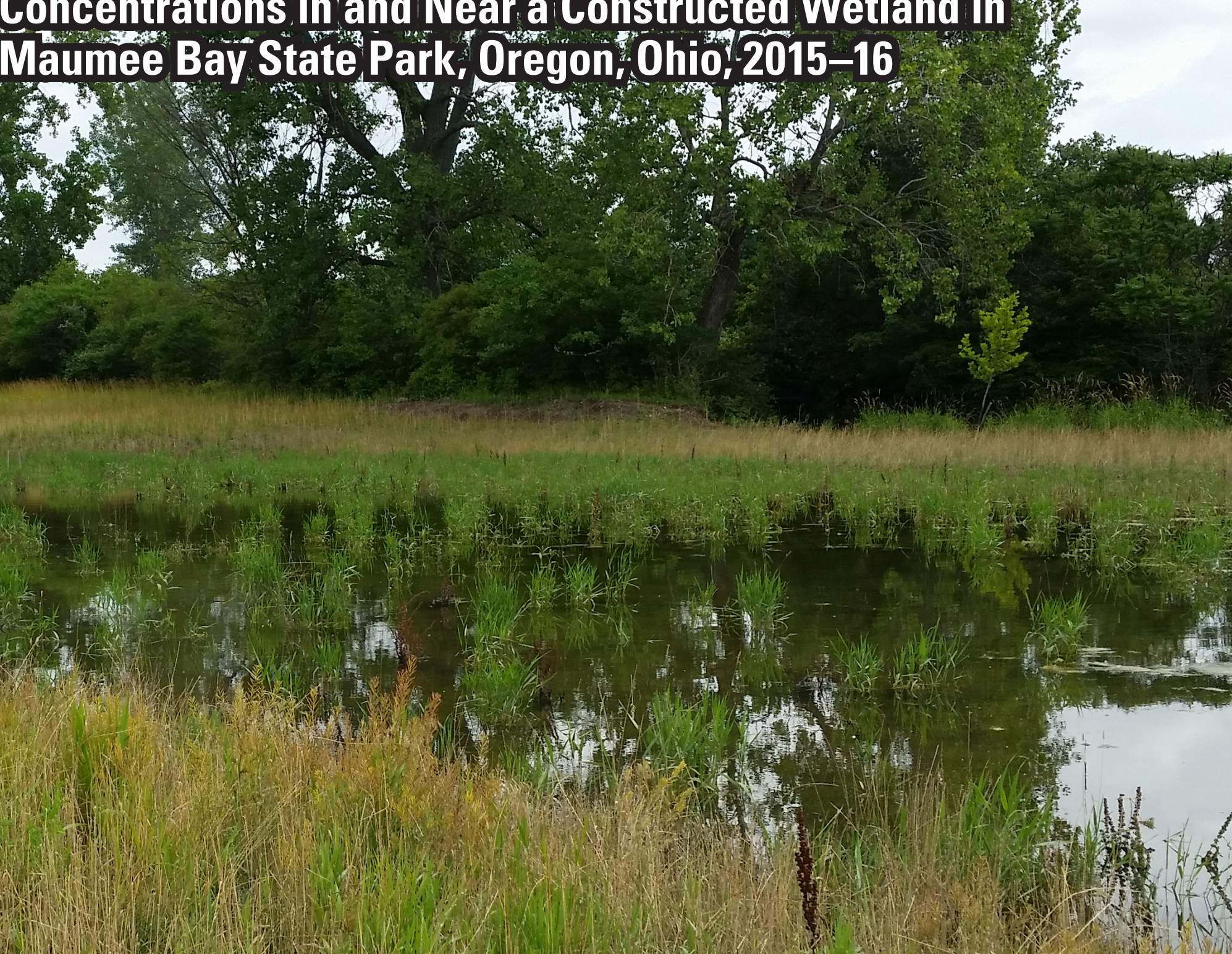

Scientific nvestigations Report 2018-5127 
Cover: Photo of wetland adjacent to Berger Ditch, Oregon, Ohio, July 8, 2015, photograph by Christopher Kephart, U.S. Geological Survey. Back cover: Photo of wetland adjacent to Berger Ditch, Oregon, Ohio, February 3, 2016, photograph by Christopher Kephart, U.S. Geological Survey. 


\section{Escherichia coli and Microbial Source Tracking Marker Concentrations in and Near a Constructed Wetland in Maumee Bay State Park, Oregon, Ohio, 2015-16}

By Christopher M. Kephart, Amie M.G. Brady, and Ryan W. Jackwood

Prepared in cooperation with the University of Toledo

Scientific Investigations Report 2018-5127 


\title{
U.S. Department of the Interior \\ DAVID BERNHARDT, Acting Secretary
}

\author{
U.S. Geological Survey \\ James F. Reilly II, Director
}

U.S. Geological Survey, Reston, Virginia: 2019

For more information on the USGS - the Federal source for science about the Earth, its natural and living resources, natural hazards, and the environment-visit https://www.usgs.gov or call 1-888-ASK-USGS.

For an overview of USGS information products, including maps, imagery, and publications,

visit https://store.usgs.gov.

Any use of trade, firm, or product names is for descriptive purposes only and does not imply endorsement by the U.S. Government.

Although this information product, for the most part, is in the public domain, it also may contain copyrighted materials as noted in the text. Permission to reproduce copyrighted items must be secured from the copyright owner.

Suggested citation:

Kephart, C.M., Brady, A.M.G., and Jackwood, R.W., 2019, Escherichia coli and microbial source tracking marker concentrations in and near a constructed wetland in Maumee Bay State Park, Oregon, Ohio, 2015-16: U.S. Geological Survey Scientific Investigations Report 2018-5127, 13 p., https://doi.org/10.3133/sir20185127.

ISSN 2328-0328 (online) 


\section{Contents}

Abstract

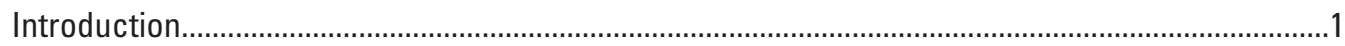

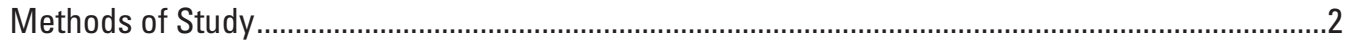

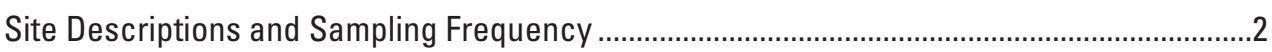

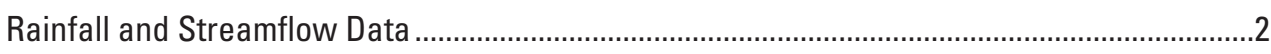

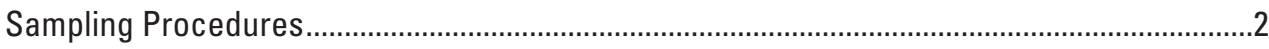

Laboratory Analyses and Associated Laboratory Quality Control .............................................4

Escherichia coli Analysis ...............................................................................................

Microbial Source Tracking Marker Analyses ..................................................................4

DNA Extraction and qPCR Analyses......................................................................

Standard Curves and Quantifying Microbial Source Tracking Markers ...................4

Quality Control Measures of Variability and Bias............................................................................

Escherichia coli and Microbial Source Tracking Marker Concentrations at Selected Sites

Entering Maumee Bay, Lake Erie..............................................................................................

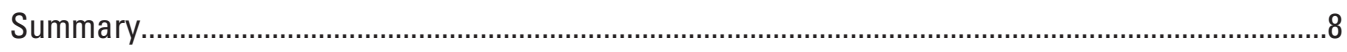

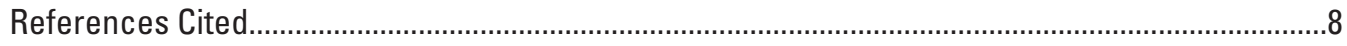

Appendix 1. Concentrations of Escherichia coli and microbial source tracking markers at

Berger Ditch, wetland, and Maumee Bay sites, Oregon, 0hio, 2015-16 ............................10 


\section{Figures}

1. Map showing location of sample collection sites in Maumee Bay State Park, Oregon, Ohio, 2015-16..

2. Boxplots showing concentrations of the general marker GenBac and Escherichia coli during dry- and wet-weather sampling conditions Maumee Bay State Park, Oregon, Ohio, 2015-16.

\section{Tables}

1. Standard curve characteristics and limits of detection and quantification for microbial source tracking markers.

2. Quality-control concurrent replicate data for Escherichia coli and microbial source tracking markers, Maumee Bay State Park, Oregon, Ohio, 2014-16.

3. Summary statistics for detections of host-associated microbial source tracking markers in samples collected at Maumee Bay State Park, Oregon, Ohio, 2015-16.

\section{Conversion Factors}

U.S. customary units to International System of Units

\begin{tabular}{lcl}
\hline \multicolumn{1}{c}{ Multiply } & By & \multicolumn{1}{c}{ To obtain } \\
\hline inch (in.) & Length & millimeter $(\mathrm{mm})$ \\
foot (ft) & 25.4 & meter $(\mathrm{m})$ \\
mile (mi) & 0.3048 & kilometer $(\mathrm{km})$ \\
yard (yd) & 1.609 & meter $(\mathrm{m})$ \\
\hline & 0.9144 & \\
\hline square mile $\left(\mathrm{mi}^{2}\right)$ & Area & hectare $(\mathrm{ha})$ \\
square mile $\left(\mathrm{mi}^{2}\right)$ & 259.0 & square kilometer $\left(\mathrm{km}^{2}\right)$ \\
\hline & 2.590 & \\
\hline cubic inch $\left(\mathrm{in}^{3}\right)$ & Volume & liter $(\mathrm{L})$ \\
inch per year per foot $([\mathrm{in} / \mathrm{yr}] / \mathrm{ft})$ & 0.01639 & millimeter per year per meter \\
\end{tabular}

\section{Datum}

Horizontal coordinate information is referenced to the North American Datum of 1983 (NAD 83). 


\section{Supplemental Information}

Concentrations of Escherichia coli (E. coli) in water are reported as most probable number per 100 milliliters (MPN/100 mL) or as colony-forming units per 100 milliliters (CFU/100 mL).

Microbial source tracking markers are reported as copies per 100 milliliters.

\section{Abbreviations}

$\begin{array}{ll}\text { CFU } & \text { Colony-forming unit } \\ \text { USEPA } & \text { U.S. Environmental Protection Agency } \\ \text { FIB } & \text { Fecal indicator bacteria } \\ \text { LoB } & \text { Limit of blanks } \\ \text { LoD } & \text { Limit of detection } \\ \text { Lo0 } & \text { Limit of quantification } \\ \text { MBSP } & \text { Maumee Bay State Park } \\ \text { MST } & \text { Microbial source tracking } \\ \text { OWML } & \text { Ohio Water Microbiology Laboratory } \\ \text { qPCR } & \text { Quantitative polymerase chain reaction } \\ \text { SRL } & \text { Sample reporting limit } \\ \text { USGS } & \text { U.S. Geological Survey }\end{array}$





\title{
Escherichia coli and Microbial Source Tracking Marker Concentrations in and Near a Constructed Wetland in Maumee Bay State Park, Oregon, Ohio, 2015-16
}

\author{
By Christopher M. Kephart' ${ }^{1}$ Amie M.G. Brady ${ }^{1}$, and Ryan W. Jackwood ${ }^{2}$
}

\section{Abstract}

Elevated Escherichia coli (E. coli) concentrations at the Maumee Bay State Park (MBSP) Lake Erie beach have resulted in frequent recreational water-quality advisories. After the construction of a wetland along Berger Ditch in Maumee Bay State Park, Oregon, Ohio, samples were collected and analyzed for concentrations of $E$. coli and microbial source tracking (MST) markers. This study was done by the U.S. Geological Survey, in cooperation with the University of Toledo, to provide data that can be used to help evaluate the effects of the wetland on water quality in MBSP. From July 2015 to February 2016, 116 samples were collected from six sites. Median GenBac (general marker) and E. coli concentrations were higher in samples from Berger Ditch sites than in samples from the wetland sites. No statistically significant difference was found between median E. coli concentrations in samples collected at Berger Ditch sites upstream and downstream from the wetland. The frequency of detection of the human-associated Bacteroides MST marker (HF183) decreased from 39 percent upstream from the wetland to 22 percent downstream from the wetland; however, the HF183 median concentrations from these two groups of samples were nearly the same $(2,700$ to 2,800 copies per 100 milliliters from upstream to downstream). The waterfowlassociated Helicobacter MST marker (GFD) was detected in 13 percent of samples from the Berger Ditch site upstream from the wetland, although it was not detected in samples from the Berger Ditch site downstream from the wetland. The ruminant-associated MST marker, Rum2Bac, was not detected at any site during this study.

\footnotetext{
${ }^{1}$ U.S. Geological Survey.
}

${ }^{2}$ University of Toledo.

\section{Introduction}

Exposure to microbiological pathogens in water contaminated by human and animal feces poses a significant human health risk (World Health Organization [WHO], 2003). The U.S. Environmental Protection Agency (USEPA, 2012) has developed bacterial water-quality criteria to protect recreational water users from exposure to pathogens (such as bacteria, viruses, and protozoa) at concentrations likely to cause illness. These criteria are based on concentrations of fecal indicator bacteria (FIB), such as Escherichia coli (E. coli) and enterococci, which are used to estimate the potential occurrence of pathogens. FIB generally are nonpathogenic and ubiquitous in human and animal feces. Standard methods used to determine concentrations of FIB do not provide information about the source of contamination (Boehm and others, 2009 and 2013); therefore, other techniques are used to supplement FIB monitoring data to help identify FIB contributions from human sources. Human-source FIB are of particular concern because they are expected to pose a higher risk to public health than sources of non-human origin (WHO, 1999 and 2003; Colford and others, 2007; Soller and others, 2010).

Microbial source tracking (MST) can be used to identify and characterize dominant sources of FIB in a water body, thereby enabling water managers to implement source-appropriate remediation strategies to improve water quality. There are currently no standard methods for MST. One of the most commonly used MST methods uses quantitative polymerase chain reaction (qPCR) to detect and enumerate molecular markers; however, no one single method has been identified as the best method for determining sources.

Sources of bacterial contamination contributing to recreational water at Maumee Bay State Park Lake Erie beach in Oregon, Ohio, are not well-characterized. Runoff from fields where biosolids have been applied and septic system failures in the watershed may be contributing to high levels of fecal contamination. Effluent from drainage tiles in fields where biosolids have been applied as fertilizer are known to flow to Wolf Creek and Berger Ditch. Waterfowl, including Larus spp. 
(gulls) and Branta canadensis (Canada geese), are also potential contributors of fecal contamination to recreational water at Maumee Bay State Park Lake Erie beach.

In the summer of 2015, a novel wetland was constructed to demonstrate and quantify the ability of ecosystem services to reduce nutrients and fecal microorganisms in Berger Ditch. Concentrations of $E$. coli elevated above background conditions are frequently detected in water at the Maumee Bay State Park Lake Erie beach, leading to beach advisories (Francy and others, 2013; https://ny.water.usgs.gov/maps/nowcast/). Berger Ditch, which discharges to Lake Erie just east of the beach, has previously been characterized as having an important effect on water quality at and near the beach (Francy and others, 2005).

This report describes the results of research done by the U.S. Geological Survey (USGS), in cooperation with the University of Toledo, to evaluate the effects of a constructed wetland on selected microbiological water-quality constituents in Berger Ditch and Maumee Bay State Park Lake Erie beach. This research is part of a larger effort by the University of Toledo to evaluate the effectiveness of that wetland and other restoration efforts, including a restored floodplain for Wolf Creek. A total of 116 samples were collected from six sites from July 2015 to February 2016 and analyzed for concentrations of E. coli and several MST markers (general Bacteroides - human-, waterfowl-, and ruminant-associated). The results are presented in this report.

\section{Methods of Study}

\section{Site Descriptions and Sampling Frequency}

With a drainage area of approximately 16 square miles $\left(\mathrm{mi}^{2}\right)$, Berger Ditch flows from south to north and empties into Maumee Bay in Lake Erie 230 feet ( $\mathrm{ft}$ ) east of the Maumee Bay State Park (MBSP) Lake Erie beach (fig. 1). Berger Ditch receives flow from Wolf Creek (not shown) which drains $10.7 \mathrm{mi}^{2}$. Land use surrounding Berger Ditch and Wolf Creek consists primarily of farmland and single-family residences.

Adjacent to Berger Ditch to the west is the wetland designed by the University of Toledo. The wetland is hydraulically connected to Berger Ditch by a holding pond $\left(3,000\right.$ square meters $\left[\mathrm{m}^{2}\right]$ × $3 \mathrm{~m}\left[32,292 \mathrm{ft}^{2} \times 9.84 \mathrm{ft}\right]$ in depth). From this holding pond, water is pumped through subsurface distribution pipes into the first of three subsurface flow wetland cells (each 2,800 $\mathrm{m}^{2}\left[30,139 \mathrm{ft}^{2}\right]$ in area). The wetland cells were constructed by excavating soil and backfilling $0.6 \mathrm{~m}$ $(1.97 \mathrm{ft})$ of limestone gravel and $0.1 \mathrm{~m}(0.328 \mathrm{ft})$ of coarse aggregate, topped with $0.2 \mathrm{~m}(0.656 \mathrm{ft})$ of on-site topsoil. The wetland cells were designed as a cascading system where elevation decreases by $0.3 \mathrm{~m}(0.984 \mathrm{ft})$ between each cell, allowing water to passively flow from the first through the third cell and then to Berger Ditch. Water flows through the subsurface gravel of each wetland cell until entering collection pipes that direct flow between wetland cells. This process is repeated until water is discharged into Berger Ditch and continues toward Maumee Bay. Water-level control structures (WLCSs) provide access for water-sample collection prior to the first wetland cell (WLCS-1), between the first and second wetland cells (WLCS-2), between the second and third wetland cells (WLCS-3), and between the third wetland cell and Berger Ditch (WLCS-4). The retention time for the wetland at the time of this study was calculated to be 2.1 days. This calculation was based on the void space within the wetland cells and the pumping rate from the holding pond.

Sampling was done at six sites as part of this study (fig. 1). Generally, samples were collected twice per weekMonday and Wednesday - for 12 weeks. In Berger Ditch, one site (W1) is upstream from the wetland adjacent to the USGS streamgage (station number 04194085). Three sampling sites are within the wetland at WLCS-1 (W2), WLCS-3 (W4), and WLCS-4 (W5). Samples were collected at site W4 instead of site W5 when WLCS-4 was submerged in overflow water from Berger Ditch after a rainfall event. Another site (W6) is located in Berger Ditch, downstream from where the wetlandtreated water discharges to Berger Ditch. Finally, site (M3) is in Maumee Bay of Lake Erie in the third swimming cove west of the mouth of Berger Ditch.

\section{Rainfall and Streamflow Data}

Rainfall data were obtained from a National Weather Service (NWS) station at Toledo Executive Airport (Station Identifier: Toledo Metcalf Field, WBAN: 04848) by accessing the historical data from the National Oceanic and Atmospheric Administration (NOAA, 2016). Daily rainfall amounts were tabulated, and the sum of the 2 days prior to the day of sampling was calculated for each sample. Samples collected when the sum of the previous 2 days of rainfall was greater than 0.56 inches were classified as wet-weather samples, whereas samples collected when the previous 2 days of rainfall was 0.56 inches or less were classified as dry-weather samples. This classification threshold was determined by examining the distribution of the previous 2-day rainfall data during the entire study period and calculating the 90th percentile.

\section{Sampling Procedures}

Samples were collected into sterile 1-liter polypropylene bottles using the hand-dip method as described in the USGS National Field Manual Section 7.1.2.A (USGS, 2014). WLCS sites were sampled by opening the concrete hatch and dipping the sample bottle into the pooled water contained therein. Samples were maintained on ice during transport to the University of Toledo Lake Erie Center laboratory, Oregon, Ohio, and during handling and transport to the Ohio Water Microbiology Laboratory (OWML) in Columbus, Ohio. Two 


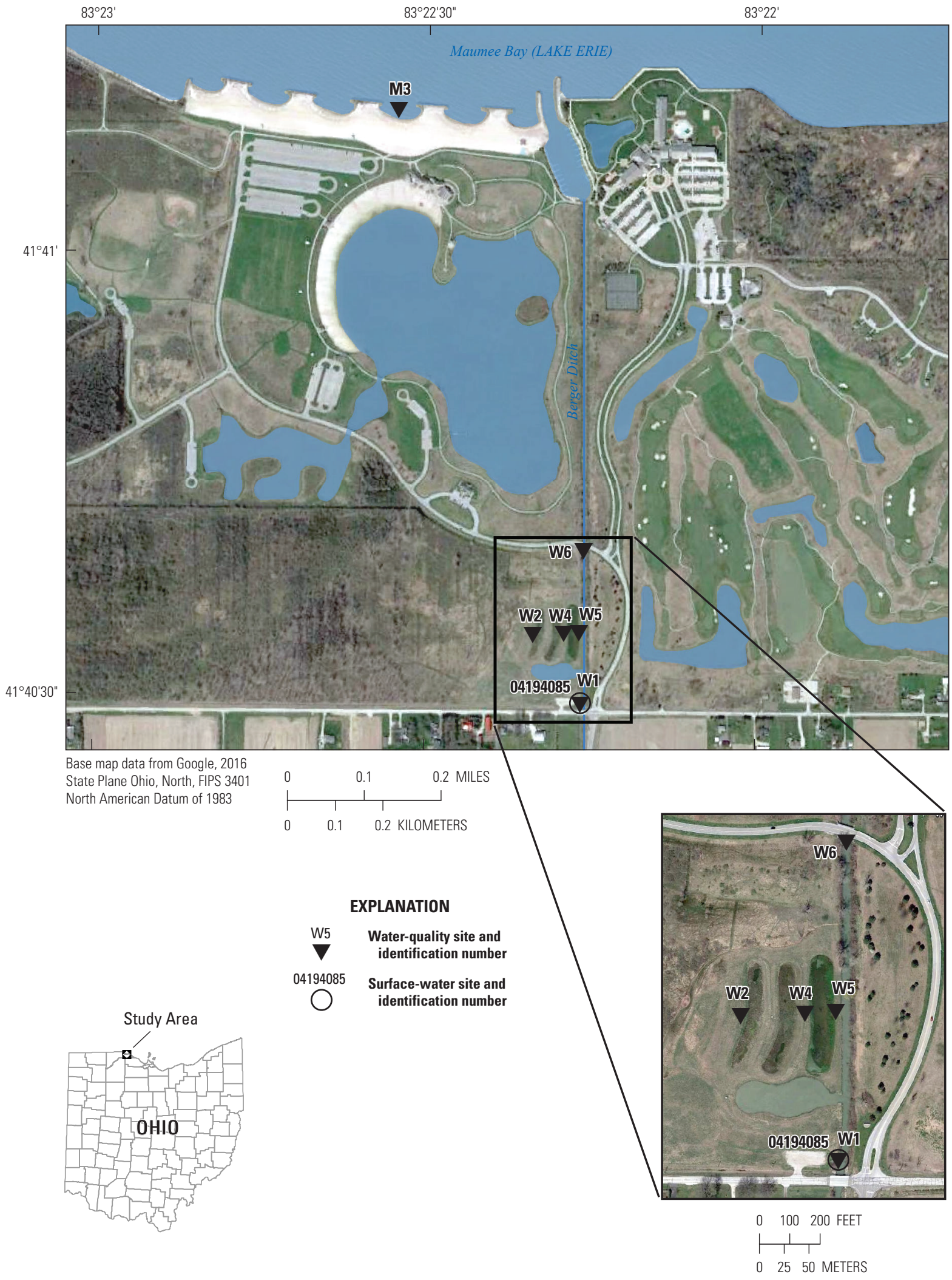

Figure 1. Location of sample collection sites in Maumee Bay State Park, Oregon, Ohio, 2015-16. 
concurrent field replicate samples were collected during the sampling period, both from site W1. Most samples were collected by University of Toledo personnel and shipped to the OWML for processing within 24 hours. Samples collected outside the routine schedule were collected by USGS personnel.

\section{Laboratory Analyses and Associated Laboratory Quality Control}

\section{Escherichia coli Analysis}

For those samples collected by USGS personnel (collected on February 3, 2016) and all samples collected at Maumee Bay cove 3 (site M3), E. coli concentrations were determined by use of the Colilert Quanti-Tray/2000 method (IDEXX Laboratories, Inc.; Westbrook, Maine). Results for the water samples were recorded as the most probable number per 100 milliliters of sample (MPN/100 mL). The two concurrent replicate samples were processed by use of the Colilert method.

For those samples collected by University of Toledo personnel at sites W1, W2, W4, W5, and W6, analyses for E. coli concentrations were done using the modified MTEC membrane-filtration method (USEPA, 2009). The concentrations of $E$. coli in the samples were recorded as colony-forming units per 100 milliliters (CFU/100 mL).

\section{Microbial Source Tracking Marker Analyses}

\section{DNA Extraction and qPCR Analyses}

In the OWML, an aliquot of each water sample (up to 100 milliliters $[\mathrm{mL}]$ ) was filtered through a 0.4-micrometer, 47-millimeter polycarbonate filter (Whatman; Florham Park, N.J.). Filters were then folded aseptically and placed into 2-mL screw-cap vials containing 0.3 grams of acid-washed glass beads (Sigma-Aldrich Corp.; St. Louis, Mo.). Negative controls (filter blanks) were filtered each day that samples were processed using sterile buffered water. Filtered samples were then stored at -70 degrees Celsius $\left({ }^{\circ} \mathrm{C}\right)$ until subsequent analysis.

Samples underwent DNA extraction by means of the DNA-EZ extraction kit from GeneRite (North Brunswick, N.J.). The extraction was done according to the manufacturer's instructions, except that no prefilter was used. Negative extraction controls (extraction blanks), consisting of a 2-mL vial containing only acid-washed glass beads, were processed with each batch of extractions. DNA extracts were stored at $4{ }^{\circ} \mathrm{C}$ until subsequent analysis by qPCR within 5 days of extraction.

Sample extracts were analyzed by qPCR for four MST markers: a general Bacteroides marker (GenBac) (Siefring and others, 2008), a human-associated Bacteroides marker (HF183) (Bernhard and Field, 2000; Seurinck and others, 2005), a waterfowl-associated Helicobacter marker (GFD) (Green and others, 2012), and a ruminant-associated Bacteroides marker (Rum2Bac) (Mieszkin and others, 2010). All qPCR analyses were performed using either an Applied Biosystems StepOne Plus or Model 7500 thermal cycler (Applied Biosystems; Foster City, Calif.). All samples were analyzed in duplicate. No-template controls (qPCR blanks), consisting of molecular-grade sterile water instead of DNA extract, were included on each qPCR plate in duplicate. For all samples, matrix inhibition was tested using matrix spikes, and results from diluted samples were used if inhibition was detected (Francy and others, 2017).

\section{Standard Curves and Quantifying Microbial Source Tracking Markers}

Standard curves were generated using plasmids containing the sequences for each of the targeted MST marker genes (Francy and Stelzer, 2012). Each qPCR run included a seven-point standard curve run in duplicate. Standard curve characteristics are listed in table 1 . Amplification efficiency is calculated from the slope of the log-linear portion of the standard curve, specifically, PCR efficiency $=10^{-1 / \text { slope }}-1$

Table 1. Standard curve characteristics and limits of detection and quantification for microbial source tracking markers.

[MST, microbial source tracking; $\mathrm{R}^{2}$, coefficient of determination; qPCR, quantitative polymerase chain reaction; GenBac, general Bacteroides marker; HF183, human-associated Bacteroides marker; GFD, waterfowl-associated Helicobacter marker; Rum2Bac, ruminant-associated Bacteroides marker]

\begin{tabular}{|c|c|c|c|c|c|}
\hline \multirow{2}{*}{ MST marker } & \multirow{2}{*}{$\begin{array}{l}\text { Number of } \\
\text { standard } \\
\text { curves run }\end{array}$} & \multirow{2}{*}{$\begin{array}{c}\text { Average } \\
\text { amplification } \\
\text { efficiency } \\
\text { (percent) }\end{array}$} & \multirow{2}{*}{ Average $\mathbf{R}^{2}$ value } & Limit of detection & \multirow{2}{*}{$\begin{array}{c}\text { Limit of } \\
\text { quantification } \\
\begin{array}{c}\text { (copies/qPCR } \\
\text { reaction) }\end{array}\end{array}$} \\
\hline & & & & $\begin{array}{l}\text { (copies/qPCR } \\
\text { reaction) }\end{array}$ & \\
\hline GenBac & 6 & 96 & 0.998 & 3 & 11 \\
\hline HF183 & 6 & 101 & 0.998 & 25 & 66 \\
\hline Rum2Bac & 6 & 100 & 0.997 & 21 & 42 \\
\hline
\end{tabular}


(Bustin and others, 2009). Conversion of qPCR output to MST marker concentrations was done by interpolating from these standard curves.

To aid in the interpretation of qPCR results, limit of blank (LoB), limit of detection (LoD), and limit of quantification (LoQ) were determined for each assay to describe the lowest concentration of each MST marker that can be differentiated from blank sample results and can be reliably detected and quantified (Francy and others, 2017). The LoB is the lowest concentration that can be reported with 95 -percent confidence to be greater than the concentration of the blanks; it was determined for each qPCR run on the basis of results from negative filtration controls, negative extraction controls, and no-template controls. The LoB was not used to report results unless it was greater than the LoD, in which case the LoB replaced the LoD. The LoD is the lowest concentration of a marker that can be detected with 95-percent confidence that it is a true detection and distinguishable from the blank sample results; LoD was determined by analyzing at least 10 replicates of each of several dilutions of a positive control. The LoQ is the lowest concentration of each MST marker that can be accurately quantified and is calculated from the standard deviation of the LoD replicates. If a sample result was less than the LoQ but greater than the LoD, the result was qualified as an estimate. If the MST marker was not detected in a sample or if the concentration was less than the LoD, then results were reported as less than the sample reporting limit $(<\mathrm{SRL})$. The SRL is specific to each sample and is calculated using the LoD, taking into account the dilution analyzed and the initial sample volume filtered. The LoD and LoQ for each MST assay are listed in table 1.

\section{Quality Control Measures of Variability and Bias}

Two field concurrent replicates were collected and analyzed during this study, both from site W1 (table 2, fig. 1). For $E$. coli concentrations, the absolute value log difference (AVLD) for each replicate pair was $0 \mathrm{MPN} / 100 \mathrm{~mL}$. For the GenBac and HF183 MST markers, the AVLDs ranged from
0.01 to 0.02 copies $/ 100 \mathrm{~mL}$. For the GFD and Rum2Bac MST markers, results were less than the detection limit for both replicates.

Among the various negative control samples, 25 filter blanks, 20 extraction blanks, and the 23 qPCR blanks were analyzed. None of the results from these quality-control samples required removal of any data from the datasets. Additionally, none of the results from the negative control analyses required adjustment of established limits of detection or quantification.

\section{Escherichia coli and Microbial Source Tracking Marker Concentrations at Selected Sites Entering Maumee Bay, Lake Erie}

Based on the distribution analysis of the rainfall data, samples were classified as occurring during dry or wet weather. Wet-weather conditions occurred during three of the sampling dates with a total of 15 samples. This equates to 13 percent of the 23 sampling dates as well as 13 percent of the 116 total samples collected.

Selected statistical tests were performed to evaluate differences in median concentrations between sampling sites and to evaluate the correlation between the GenBac marker and $E$. coli concentrations. An alpha level of 0.05 was used to assess statistical significance for all tests.

GenBac MST marker and E. coli concentrations, grouped into dry (boxplots) and wet weather (closed circles) sampling events, are shown in figure 2. Although there were far fewer wet-weather than dry-weather samples collected, some comparisons can be made. GenBac marker and E. coli concentrations during wet weather were in the same range as concentrations during dry weather with two notable exceptions: (1) GenBac concentrations at site W4 during wet weather were lower than concentrations during dry weather and (2) E. coli concentrations in samples collected at site W1 and site W6 during wet weather were higher than those in most or all samples collected during dry weather. Median GenBac and

Table 2. Quality-control concurrent replicate data for Escherichia coli and microbial source tracking markers, Maumee Bay State Park, Oregon, Ohio, 2014-16.

[AVLD is absolute value $\log _{10}$ difference between replicates A and B; Escherichia coli (E. coli) are reported in most probable number per 100 milliliters; microbial source tracking markers are reported in copies per 100 milliliters; GenBac, general Bacteroides marker; HF183, human-associated Bacteroides marker]

\begin{tabular}{|c|c|c|c|c|c|c|c|c|c|}
\hline Date & \multicolumn{3}{|c|}{ E. coli } & \multicolumn{3}{|c|}{ GenBac } & \multicolumn{3}{|c|}{ HF183 } \\
\hline $2 / 3 / 2016$ & 330 & 330 & 0.00 & $5.80 \mathrm{E}+07$ & $7.96 \mathrm{E}+07$ & 0.02 & $1.85 \mathrm{E}+04$ & $2.09 \mathrm{E}+04$ & 0.01 \\
\hline
\end{tabular}




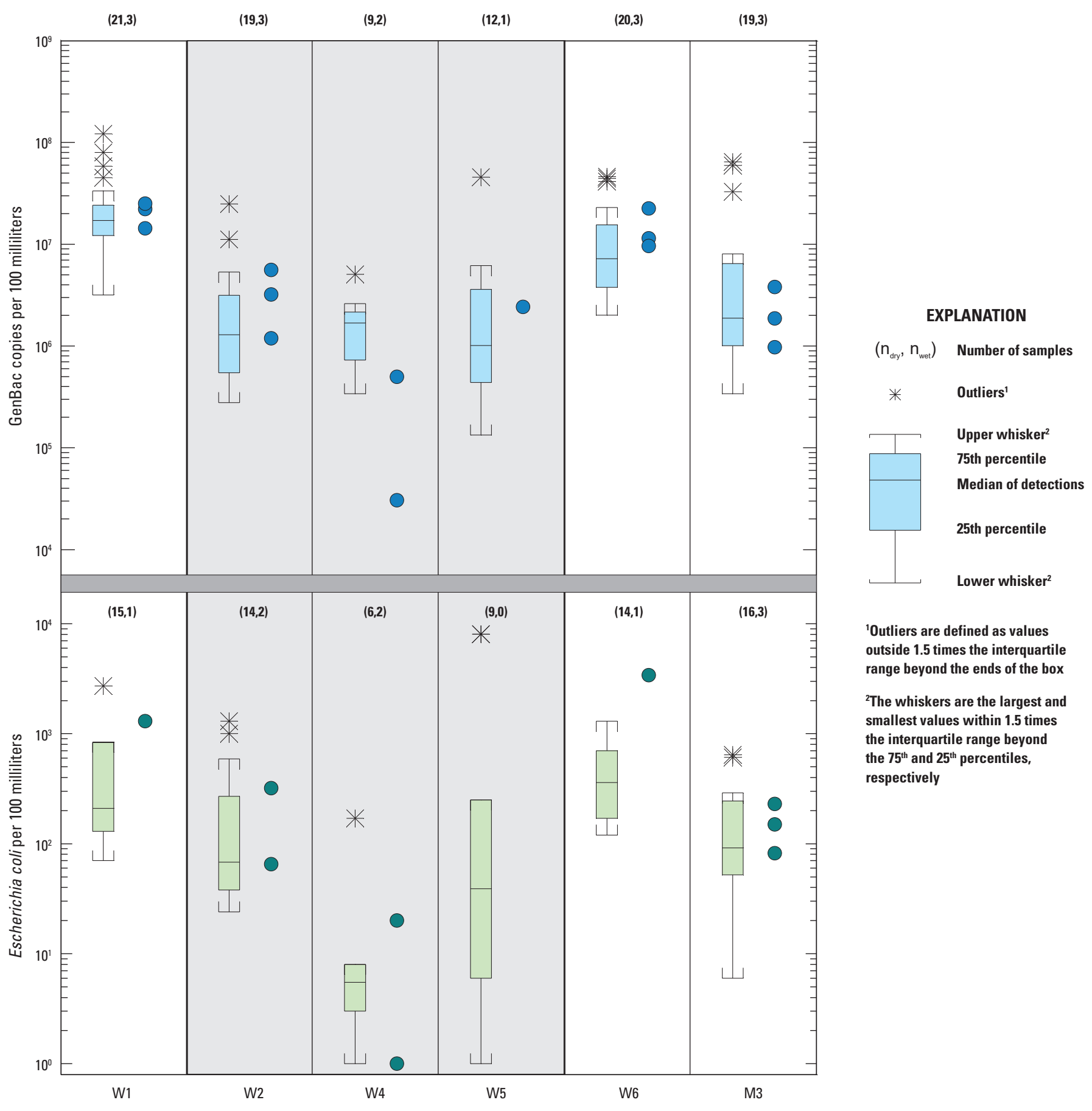

Figure 2. Concentrations of the general marker GenBac and Escherichia coli during dry- and wet-weather sampling conditions Maumee Bay State Park, Oregon, Ohio, 2015-16. (Wet-weather samples are represented by closed circles. Boxplots are not drawn for wet-weather sample concentrations as, at most, there were only three such occurrences at a given site. Escherichia coli concentrations include both most probable number/100 milliliters (Colilert analysis) and colony-forming units/100 milliliters (mod mTEC analysis). Sites in the plot with gray shaded vertical panels are in the constructed wetland.) 
E. coli concentrations, regardless of precipitation, were highest at sites W1 and W6, both in Berger Ditch. HF183, GFD, and Rum2Bac MST markers were not detected frequently enough at greater than the detection limit to be presented in boxplots such as those in figure 2.

Results of a Wilcoxon rank-sum test (Helsel and Hirsch, 2002) indicate that median E. coli concentrations at sites W1 and W6 (sites upstream and downstream from the wetland in Berger Ditch) were not significantly different $(p=0.43)$. However, results of this same test indicate that median GenBac marker concentrations at sites W1 and W6 were significantly different $(\mathrm{p}=0.01)$. The median GenBac concentrations at sites $\mathrm{W} 1$ and $\mathrm{W} 6$ were $1.7 \times 10^{7}$ and $7.8 \times 10^{6}$ copies per $100 \mathrm{~mL}$, respectively.

E. coli and MST marker concentration results are presented in appendix 1 . Wet-weather sampling dates $(7 / 20 / 2015$, $8 / 3 / 2015$, and $8 / 31 / 2015$ ) are shaded and detections of the MST markers HF183 and GFD are bold. The general marker (GenBac) was detected in all samples and ranged in concentration from $3.1 \times 10^{4}$ to $1.2 \times 10^{8}$ copies $/ 100 \mathrm{~mL}$. Results of Spearman's rank correlation analysis indicate that log concentrations of the GenBac marker correlate with log concentrations of E. coli ( rho $=0.51, \mathrm{p}<0.0001)$. Of the 21 detections of the HF183 human-associated marker, 14 occurred on just four sampling dates. HF 183 was detected at three or more sites on each of those four dates, and only one of the four dates was classified as wet weather (appendix 1). The Rum2Bac marker was not detected at greater than the sample reporting limits in any sample (data not shown).

Summary statistics with combined wet and dry weather results for the HF183 and GFD MST markers are presented in table 3. Although the percent detection of HF183 was lower for Berger Ditch site W6 (22 percent) than for W1 (39 percent), the median concentration of those detections was about the same for W1 and W6 $\left(2.7 \times 10^{3}\right.$ and $2.8 \times 10^{3}$ copies $/ 100 \mathrm{~mL}$ ). The GFD waterfowl maker was detected in 13 samples, most frequently at site W5. This was unexpected because this site was a WLCS site and thus closed off from direct contact with waterfowl feces, but the presence of the GFD marker could have been the result of waterfowl using the wetland holding pond. Two samples contained GFD concentrations nearly $1 \log$ and $3 \operatorname{logs}$ greater than all other detections $\left(6.0 \times 10^{4}\right.$ copies/100 mL at site $\mathrm{W} 1$ on September 23, 2015 , and $1.2 \times 10^{6}$ copies $/ 100 \mathrm{~mL}$ at site M3 on August 31, 2015).

In this study, samples were collected and analyzed for E. coli and MST marker concentrations at six sites in and near a subsurface treatment wetland constructed in Maumee Bay State Park. These data are available for review or download from the USGS National Water Information System Web Interface and can be found using the hyperlinks associated with the site numbers in table 3 (USGS, 2018). Given the low frequency of detection of MST markers such as HF183 and GFD, a larger dataset with multiple years of sampling under varied hydrologic conditions would likely help to characterize fecal sources while also providing more information with which to evaluate the efficacy of restoration efforts. Additionally, given the estimated 2-day retention time of the wetland, high-frequency synoptic sampling during dry- and wet-weather conditions could improve the understanding of the wetland's effect on the reduction of fecal microorganism contributions to Lake Erie.

Table 3. Summary statistics for detections of host-associated microbial source tracking markers in samples collected at Maumee Bay State Park, Oregon, Ohio, 2015-16.

[Microbial source tracking markers are reported in copies per 100 milliliters; ND, not determined because there were not enough detected concentrations; median concentrations were reported only when there were greater than two detections; HF183, human-associated Bacteroides marker; GFD, waterfowlassociated Helicobacter marker]

\begin{tabular}{|c|c|c|c|c|c|c|c|c|c|}
\hline \multirow[b]{2}{*}{ Site } & \multirow[b]{2}{*}{$\begin{array}{c}\text { Number } \\
\text { of } \\
\text { samples }\end{array}$} & \multicolumn{4}{|c|}{ HF183 Marker } & \multicolumn{4}{|c|}{ GFD Marker } \\
\hline & & $\begin{array}{l}\text { Percent } \\
\text { detection }\end{array}$ & $\begin{array}{c}\text { Range of marker } \\
\text { concentration }\end{array}$ & $\begin{array}{c}\text { Mean } \\
\text { concen- } \\
\text { tration }\end{array}$ & $\begin{array}{l}\text { Median } \\
\text { concen- } \\
\text { tration }\end{array}$ & $\begin{array}{l}\text { Percent } \\
\text { detection }\end{array}$ & $\begin{array}{c}\text { Range of marker } \\
\text { concentration }\end{array}$ & $\begin{array}{l}\text { Mean } \\
\text { concen- } \\
\text { tration }\end{array}$ & $\begin{array}{l}\text { Median } \\
\text { concen- } \\
\text { tration }\end{array}$ \\
\hline W1 & 23 & 39 & $8.40 \mathrm{E}+02-2.50 \mathrm{E}+04$ & $7.50 \mathrm{E}+03$ & $2.70 \mathrm{E}+03$ & 13 & $1.20 \mathrm{E}+03-6.00 \mathrm{E}+04$ & $2.30 \mathrm{E}+04$ & $7.10 \mathrm{E}+03$ \\
\hline W4 & 11 & 9 & $2.10 \mathrm{E}+03$ & ND & ND & 18 & $6.90 \mathrm{E}+02-2.30 \mathrm{E}+03$ & $1.50 \mathrm{E}+03$ & ND \\
\hline W5 & 13 & 15 & $9.80 \mathrm{E}+02-3.40 \mathrm{E}+03$ & $2.20 \mathrm{E}+03$ & ND & 46 & $6.20 \mathrm{E}+02-3.50 \mathrm{E}+03$ & $1.80 \mathrm{E}+03$ & $1.60 \mathrm{E}+03$ \\
\hline
\end{tabular}




\section{Summary}

A study was conducted by the U.S. Geological Survey in cooperation with the University of Toledo to evaluate the effects of a constructed wetland on microbial water-quality constituents. Elevated Escherichia coli (E. coli) concentrations at the Maumee Bay State Park (MBSP) Lake Erie beach have resulted in frequent recreational water-quality advisories. Sources of these elevated E. coli concentrations at the beach are not well understood, but previous studies have indicated that Berger Ditch has an important effect on water quality at and near the beach. Putative sources of fecal contamination that may affect the study area include runoff and (or) drainage from fields that have been treated with biosolids applied as fertilizer, failing septic systems, and waterfowl.

As part of an effort to improve water quality at the MBSP Lake Erie beach, the University of Toledo designed and implemented a novel wetland along Berger Ditch. Sampling was done in 2015 and early 2016 to determine concentrations of E. coli and selected microbial source tracking (MST) markers in and around the wetland. The specific MST markers analyzed were a general Bacteroides marker (GenBac), a human-associated Bacteroides marker (HF183), a waterfowlassociated Helicobacter marker (GFD), and a ruminant-associated Bacteroides marker (Rum2Bac). Samples were collected from 6 sites: 2 were in Berger Ditch (W1, upstream from the wetland and W6, downstream from the wetland), 3 were in subsurface water-level control structures within the wetland (W2, before the first wetland cell; W4, between wetland cells 2 and 3; and W5, between wetland cell 3 and re-entry to Berger Ditch), and 1 was in the swimming area at the Lake Erie beach at MBSP (M3).

Median GenBac and E. coli concentrations were highest in samples from sites in Berger Ditch (W1 and W6), and lower concentrations were present in samples from wetland sites (W2, W4, and W5). The effect of the wetland (if any) on removal of $E$. coli and GenBac in Berger Ditch is uncertain. The results of a Wilcoxon rank-sum test indicate that median E. coli concentrations at sites $\mathrm{W} 1$ and W6 (sites upstream and downstream from the wetland in Berger Ditch) were not significantly different $(p=0.43)$. However, results of this same test indicate that median GenBac marker concentrations at sites $\mathrm{W} 1$ and $\mathrm{W} 6$ were significantly different $(\mathrm{p}=0.01)$. The median GenBac concentrations at sites W1 and W6 were $1.7 \times 10^{7}$ and $7.8 \times 10^{6}$ copies per 100 milliliters $(\mathrm{mL})$, respectively.

The source-associated MST markers were not detected frequently enough to draw conclusions regarding the wetland's effect on their fate and transport in Berger Ditch. In the 116 samples analyzed, HF 183 was detected only 21 times, and GFD was detected only 13 times. Rum2Bac was not detected in any of the samples analyzed. Although the percent detection of HF183 was somewhat lower at site W6 (22\%) than at site $\mathrm{W} 1(39 \%)$, the median concentration of those detections was about the same at both sites $\left(2.7 \times 10^{3}\right.$ copies $/ 100 \mathrm{~mL}$ at site $\mathrm{W} 1$ and $2.8 \times 10^{3}$ copies/100 $\mathrm{mL}$ at site W6). GFD was detected most frequently at site W5. This was unexpected because this was a subsurface site, but the presence of GFD could have resulted from waterfowl using the wetland holding pond.

Given the low frequency of detection for MST markers and the complexity of the wetland at Berger Ditch, a larger dataset with multiple years of sampling data could provide more information to evaluate the efficacy of the water-quality restoration efforts in Maumee Bay State Park. High-frequency synoptic sampling in and around the wetland during various hydrologic conditions also could provide more resolution for the effect of the wetland on microbiological constituents of concern.

\section{References Cited}

Bernhard, A.E., and Field, K.G., 2000, A PCR assay to discriminate human and ruminant feces on the basis of host differences in Bacteroides-Prevotella genes encoding 16S rRNA: Applied and Environmental Microbiology, v. 66, no. 10, p. $4571-4574$.

Boehm, A.B., Ashbolt, N.J., Colford, J.M., Dunbar, L.E., Fleming, L.E., Gold, M.A., Hansel, J.A., Hunter, P.R., Ichida, A.M., McGee, C.D., Soller, J.A., and Weisberg, S.B., 2009, A sea change ahead for recreational water quality criteria: Journal of Water Health, v. 7, no. 1, p. 9-20.

Boehm, A.B., Van De Werfhorst, L.C., Griffith, J.F., Holden, P.A., Jay, J.A., Shanks, O.C., Wang, D., and Weisberg, S.B., 2013, Performance of forty-one microbial source tracking methods: A twenty-seven lab evaluation study: Water Resources, v. 47, p. 6812-6828.

Bustin, S.A., Benes, V., Garson, J.A., Hellemans, J., Huggett, J., Kubista, M., Mueller, R., Nolan, T., Pfaffl, M.W., Shipley, G.L., Vandesompele, J., and Wittwer, C.T., 2009, Clinical Chemistry, v. 55, no. 4, p. 611-622.

Colford, J.M., Wade, T.J., Schiff, K.C., Wright, C.C., Griffith, J.F., Sandhu, S.K., Burns, S., Sobsey, M., Lovelace, G., and Weisberg, S.B., 2007, Water quality indicators and the risk of illness at beaches with nonpoint sources of fecal contamination: Epidemiology, v. 18, no. 1, p. 27-35.

Francy, D.S., Struffolino, P., Brady, A.M.G., and Dwyer, D.F., 2005, A spatial, multivariable approach for identifying proximate sources of Escherichia coli to Maumee Bay, Lake Erie, Ohio: U.S. Geological Survey Open-File Report 2005-1386, $20 \mathrm{p}$.

Francy, D.S., Brady, A.M.G., Carvin, R.B., Corsi, S.R., Fuller, L.M., Harrison, J.H., Hayhurst, B.A., Lant, J., Nevers, M.B., Terrio, P.J., and Zimmerman, T.M., 2013, Developing and implementing predictive models for estimating recreational water quality at Great Lakes beaches: U.S. Geological Survey Scientific Investigations Report 2013-5166, 68 p. 
Francy, D.S., Bushon, R.N., Brady, A.M.G., Kephart, C.M., Stelzer, E.A., and Ecker, C.D., 2017, Quality Assurance/ Quality Control Manual: Ohio Water Microbiology Laboratory, accessed April 3, 2018, at http://oh.water.usgs.gov/ micro_qaqc.htm.

Francy, D.S., and Stelzer, E.A., 2012, Microbial source tracking markers at three inland recreational lakes in Ohio, 2011: U.S. Geological Survey Open-File Report 2012-1222, 8 p.

Green, H.C., Dick, L.K., Gilpin, B., Samadpour, M., and Field, K.G., 2012, Genetic markers for rapid PCR-based identification of gull, Canada goose, duck, and chicken fecal contamination in water: Applied and Environmental Microbiology, v. 78, no. 2, p. 503-510.

Helsel, D.R., and Hirsch, R.M., 2002, Statistical Methods in Water Resources. U.S. Geological Survey Techniques of Water-Resources Investigations, Book 4, chapter A3, 522 p.

Mieszkin, S., Yala, J.F., Joubrel, R., and Gourmelon, M., 2010, Phylogenetic analysis of Bacteroidales 16S rRNA gene sequences from human and animal effluents and assessment of ruminant faecal pollution by real-time PCR: Journal of Applied Microbiology, v. 108, p. 974-984.

National Oceanic and Atmospheric Administration (NOAA), 2016, National Centers for Environmental InformationLocal Climatological Data: Asheville, N.C., accessed May 16, 2018 at https://www.ncdc.noaa.gov/cdo-web/datatools/ lcd.

Seurinck, S., Defoirdt, T., Verstraete, W., and Siciliano, S.D., 2005, Detection and quantification of the human-specific HF183 Bacteroides 16S rRNA genetic marker with realtime PCR for assessment of human faecal pollution in freshwater: Environmental Microbiology, v. 7, no. 2, p. 249-259.

Siefring, S., Varma, M., Atikovic, E., Wymer, L., and Haugland R., 2008, Improved real-time PCR assays for the detection of fecal indicator bacteria in surface waters with different instrument and reagent systems: Journal of Water and Health, v. 6 , no. 2, p. 225-237.
Soller, J.A., Schoen, M.E., Bartrand, T., Ravenscroft, J.E., and Ashbolt, N.J., 2010, Estimated human health risks from exposure to recreational waters impacted by human and nonhuman sources of faecal contamination: Water Resources, v. 44, no. 16, p. 4674-4691.

U.S. Environmental Protection Agency (USEPA), 2009, Method 1603: Escherichia coli (E. coli) in water by membrane filtration using modified membrane-thermotolerant Escherichia coli agar (modified mTEC), Washington, D.C., EPA-821-R-09-007, 24 p.

U.S. Environmental Protection Agency (USEPA), 2012, Recreational water quality criteria, Office of Water 820-F-12058, accessed April 3, 2018, at http://water.epa.gov/scitech/ swguidance/standards/criteria/health/recreation/upload/ RWQC2012.pdf.

U.S. Geological Survey (USGS), 2014, National field manual for the collection of water-quality data: U.S. Geological Survey Techniques of Water-Resources Investigations, book 9, chap. A7, accessed May 16, 2018, at http://water. usgs.gov/owq/FieldManual/.

U.S. Geological Survey (USGS), 2018, National Water Information System - Web Interface: U.S. Geological Survey web page, accessed September 10, 2018, at https://dx.doi. org/10.5066/F7P55KJN.

World Health Organization (WHO), 1999, Health-based monitoring of recreational waters: The feasibility of a new approach (the "Annapolis Protocol”): Geneva, World Health Organization.

World Health Organization (WHO), 2003, Guidelines for safe recreational water environments, Volume 1: Coastal and Freshwaters: Geneva, World Health Organization. 


\section{Appendix 1.}

Concentrations of Escherichia coli and microbial source tracking markers at Berger Ditch, wetland, and Maumee Bay sites, Oregon, Ohio, 2015-16. 
Appendix 1. Concentrations of Escherichia coli and microbial source tracking markers at Berger Ditch, wetland, and Maumee Bay sites, Oregon, Ohio, 2015-16.

[MST, microbial source tracking; E. coli, Escherichia coli; MPN, most probable number; CFU, colony forming units; mL, milliliters; GenBac, general Bacteroides marker; --, analysis not done; $<$, less than; $\mathbf{E}$, value was estimated; b, extrapolated below the limit of quantification; $\sim$, duplicate quantitative polymerase chain reaction results did not agree; wet-weather sample sets are shaded; detections of human-associated Bacteroides marker (HF183) or waterfowl-associated Helicobacter marker (GFD) are bold]

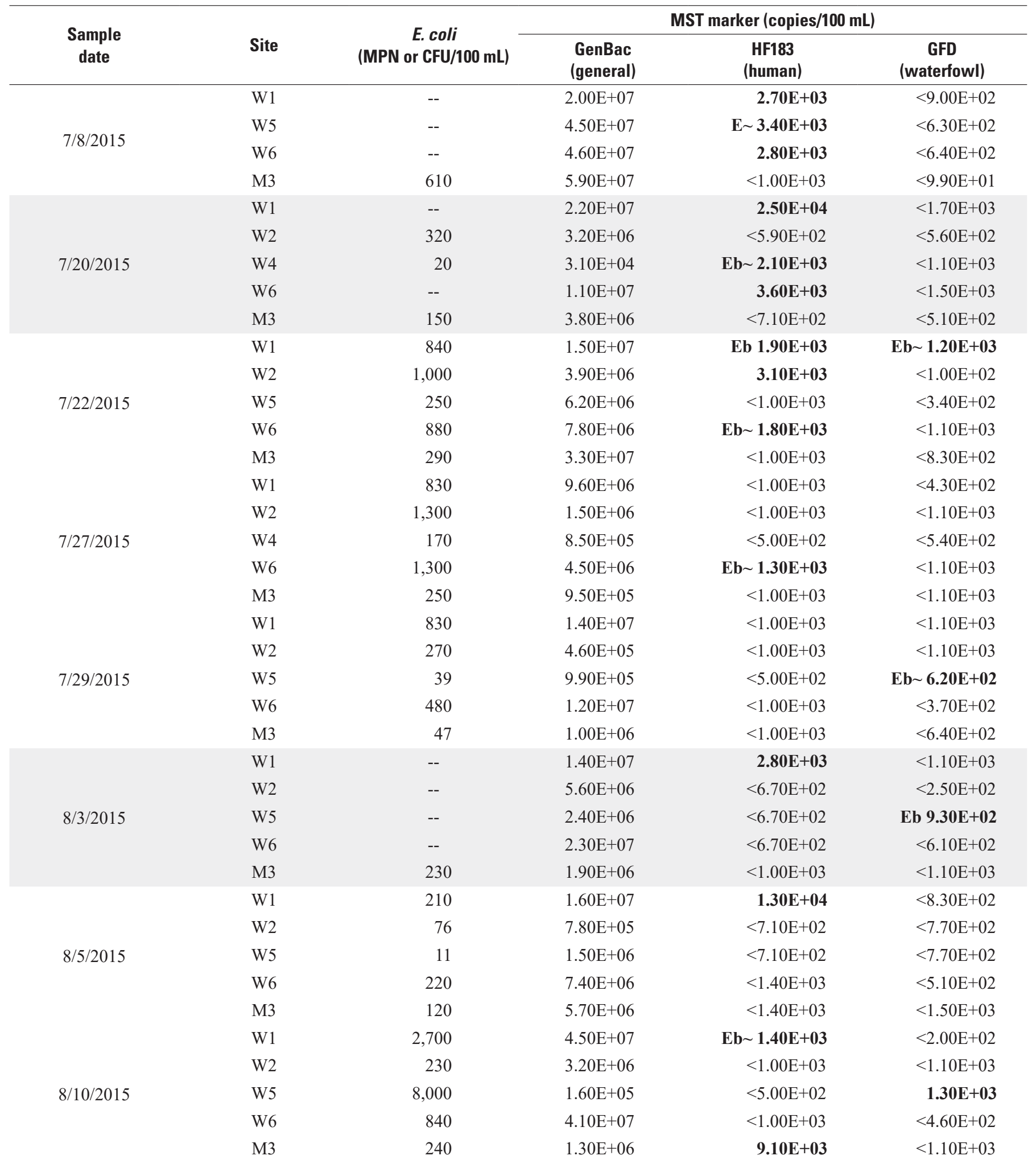


Appendix 1. Concentrations of Escherichia coli and microbial source tracking markers at Berger Ditch, wetland, and Maumee Bay sites, Oregon, Ohio, 2015-16.-Continued

[MST, microbial source tracking; E. coli, Escherichia coli; MPN, most probable number; CFU, colony forming units; mL, milliliters; GenBac, general Bacteroides marker; --, analysis not done; $<$, less than; $\mathbf{E}$, value was estimated; $\mathbf{b}$, extrapolated below the limit of quantification; $\sim$, duplicate quantitative polymerase chain reaction results did not agree; wet-weather sample sets are shaded; detections of human-associated Bacteroides marker (HF183) or waterfowl-associated Helicobacter marker (GFD) are bold]

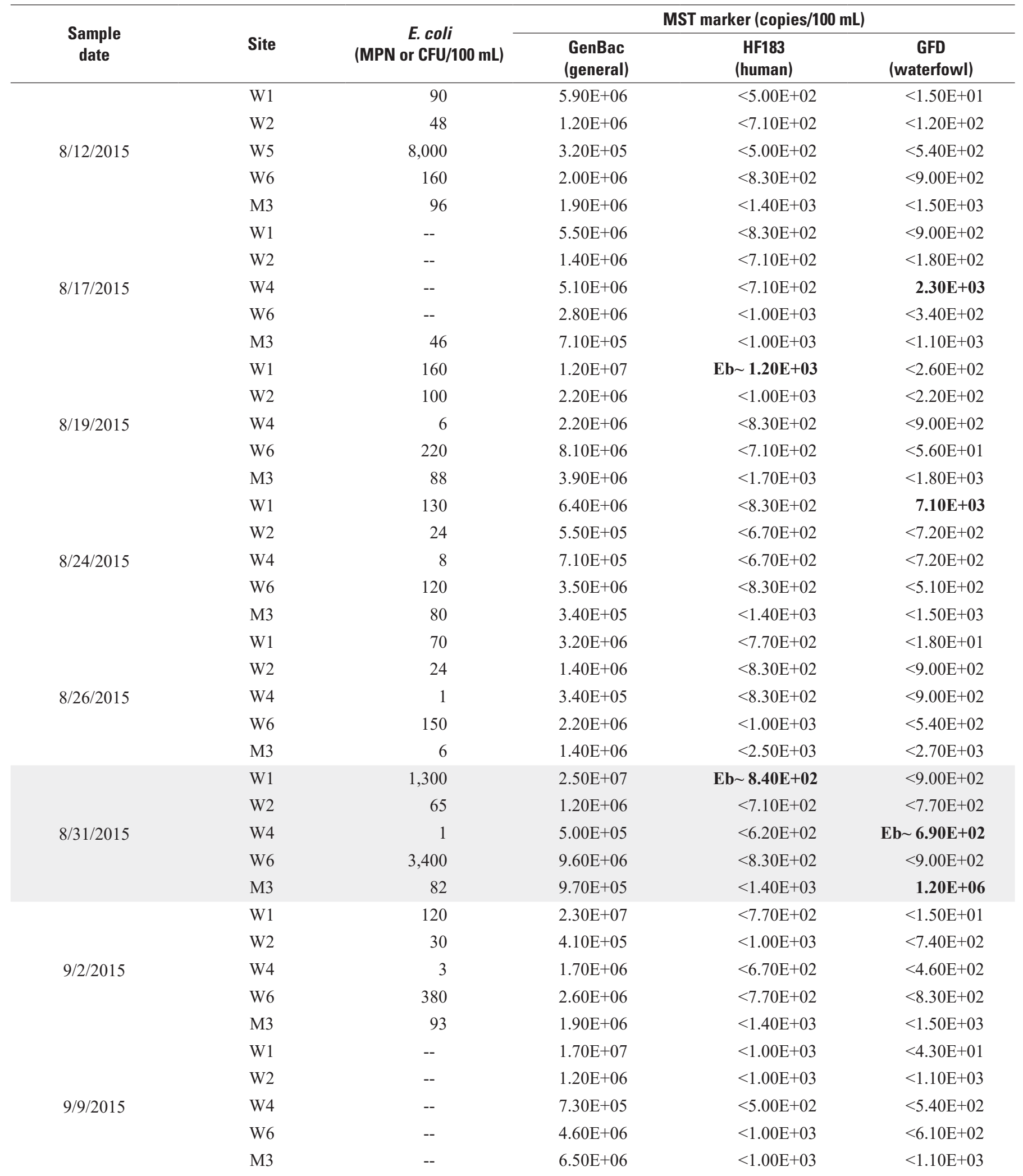


Appendix 1. Concentrations of Escherichia coli and microbial source tracking markers at Berger Ditch, wetland, and Maumee Bay sites, Oregon, Ohio, 2015-16.-Continued

[MST, microbial source tracking; E. coli, Escherichia coli; MPN, most probable number; CFU, colony forming units; mL, milliliters; GenBac, general Bacteroides marker; --, analysis not done; $<$, less than; $\mathbf{E}$, value was estimated; b, extrapolated below the limit of quantification; $\sim$, duplicate quantitative polymerase chain reaction results did not agree; wet-weather sample sets are shaded; detections of human-associated Bacteroides marker (HF183) or waterfowl-associated Helicobacter marker (GFD) are bold]

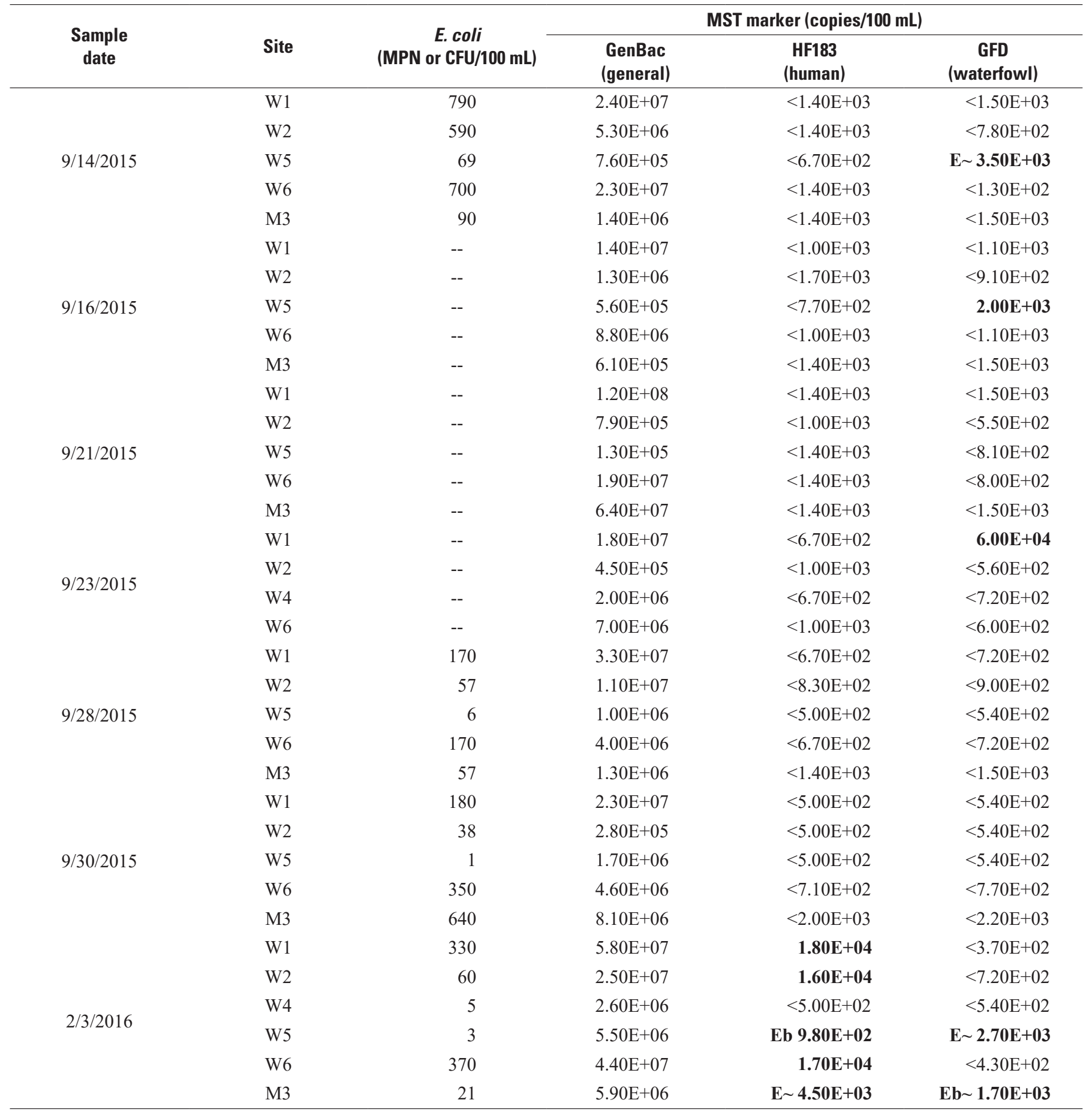


For additional information, contact:

Director, Ohio-Kentucky-Indiana Water Science Center U.S. Geological Survey

6460 Busch Blvd, Suite 100

Columbus, $\mathrm{OH}$ 43229-1737

Or visit our website at:

https://www.usgs.gov/centers/oki-water

Publishing support provided by the West Trenton

Publishing Service Center 


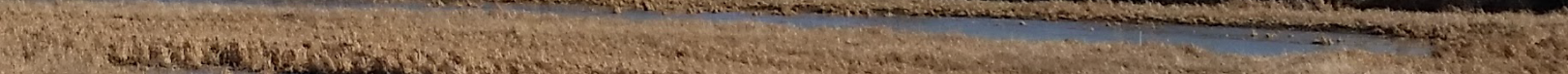

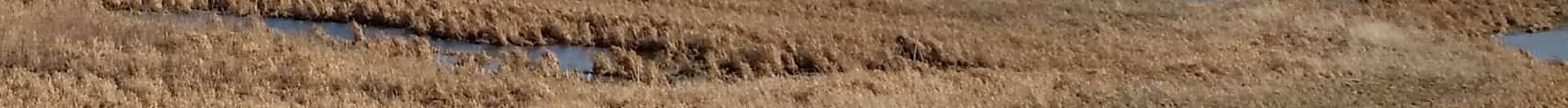

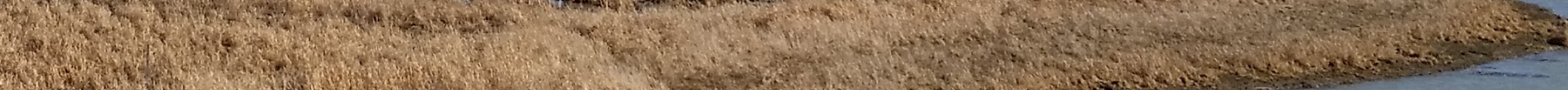
10.6.

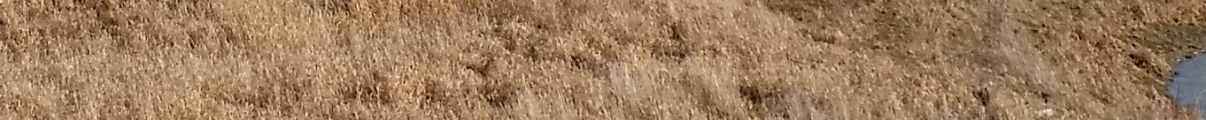

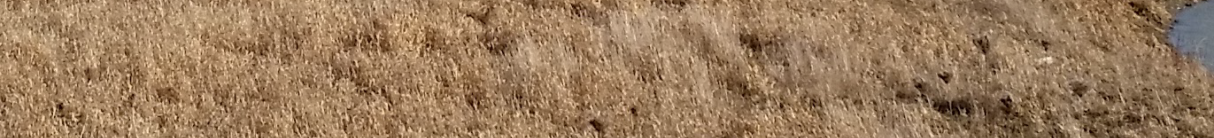

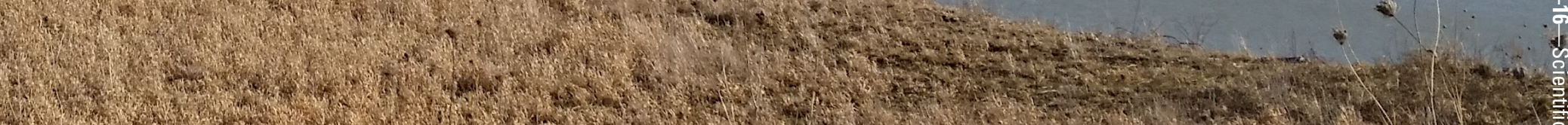

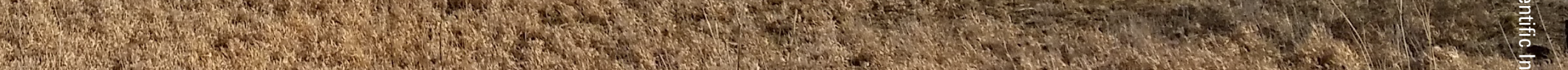

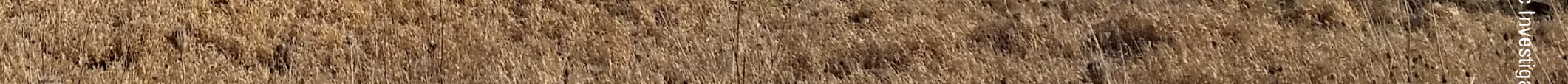

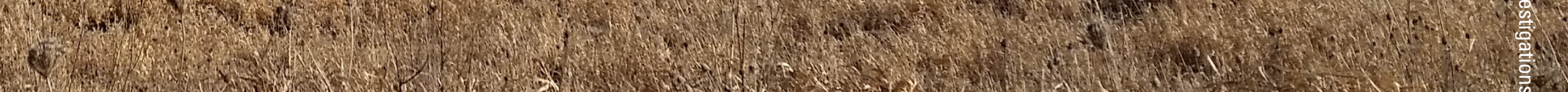
2.

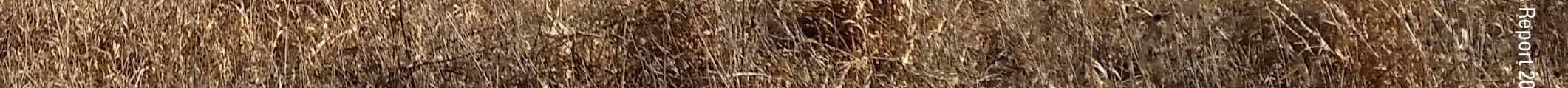
(2)

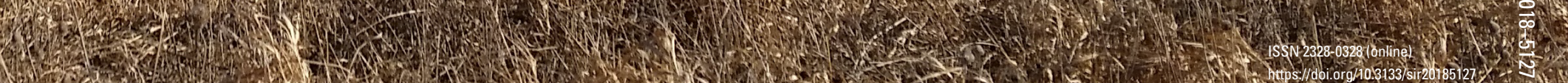

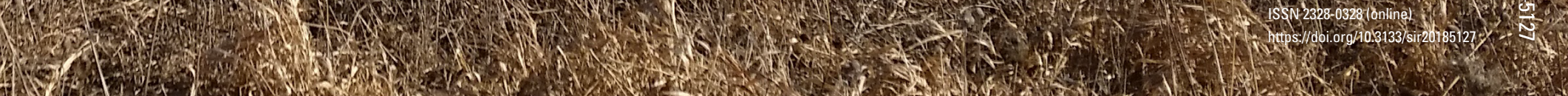

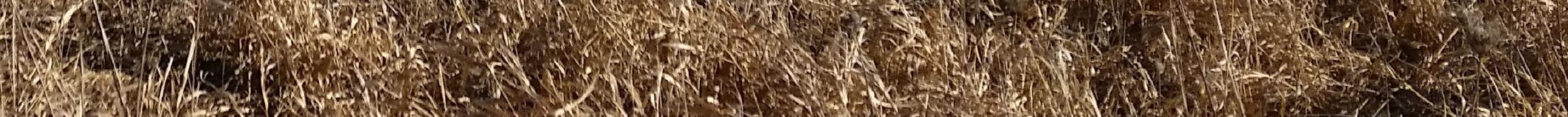

